\title{
Preparation and cytotoxicity of cisplatin-containing liposomes
}

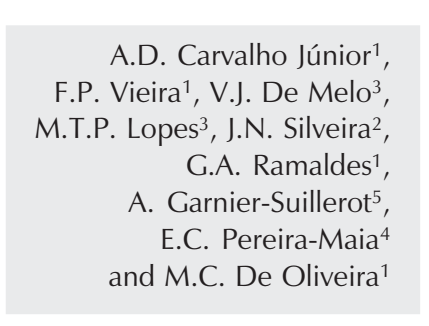

\author{
1Departamento de Produtos Farmacêuticos, \\ ${ }^{2}$ Departamento de Análises Clínicas e Toxicológicas, \\ Faculdade de Farmácia, \\ ${ }^{3}$ Departamento de Farmacologia, Instituto de Ciências Biológicas, \\ ${ }^{4}$ Departamento de Química, Instituto de Ciências Exatas, \\ Universidade Federal de Minas Gerais, Belo Horizonte, MG, Brasil \\ ${ }^{5}$ Laboratoire BioMoCeTi UMR 7033, Université Paris 13, Paris, France
}

\author{
Correspondence \\ M.C. De Oliveira \\ Departamento de Produtos \\ Farmacêuticos \\ Faculdade de Farmácia \\ UFMG \\ Av. Antônio Carlos, 6627 \\ 31270-901 Belo Horizonte, MG \\ Brasil \\ Fax: +55-31-3499-6935 \\ E-mail: monicacristina@ufmg.br \\ Research supported by FAPEMIG and \\ CNPq. A.D. Carvalho Júnior was the \\ recipient of a CAPES fellowship. \\ $\ldots \ldots \ldots \ldots \ldots \ldots \ldots$
}

Received April 10, 2006 Accepted March 26, 2007

\section{Abstract}

We encapsulated cisplatin into stealth $\mathrm{pH}$-sensitive liposomes and studied their stability, cytotoxicity and accumulation in a human small-cell lung carcinoma cell line (GLC4) and its resistant subline (GLC4/CDDP). Since reduced cellular drug accumulation has been shown to be the main mechanism responsible for resistance in the GLC4/CDDP subline, we evaluated the ability of this new delivery system to improve cellular uptake. The liposomes were composed of dioleoylphosphatidylethanolamine (DOPE), cholesteryl hemisuccinate (CHEMS), and distearoylphosphatidylethanolamine-polyethyleneglycol 2000 (DSPE-PEG 2000 ) and were characterized by determining the encapsulation percentage as a function of lipid concentration. Among the different formulations, DOPE/CHEMS/DSPE-PEG liposomes (lipid concentration equal to $40 \mathrm{mM}$ ) encapsulated cisplatin more efficiently than other concentrations of liposomes (about 20.0\%, mean diameter of $174 \mathrm{~nm}$ ). These liposomes presented good stability in mouse plasma which was obtained using a 0.24-M EDTA solution (70\% cisplatin was retained inside the liposomes after $30 \mathrm{~min}$ of incubation). Concerning cytotoxic effects, they are more effective (1.34-fold) than free cisplatin for growth inhibition of the human lung cancer cell line A549. The study of cytotoxicity to GLC4 and GLC4/ CDDP cell lines showed similar $\mathrm{IC}_{50}$ values (approximately $1.4 \mu \mathrm{M}$ ), i.e., cisplatin-resistant cells were sensitive to this cisplatin formulation. Platinum accumulation in both sensitive and resistant cell lines followed the same pattern, i.e., approximately the same intracellular platinum concentration $\left(4.0 \times 10^{-17} \mathrm{~mol} / \mathrm{cell}\right)$ yielded the same cytotoxic effect. These results indicate that long-circulating $\mathrm{pH}$-sensitive liposomes, also termed as stealth $\mathrm{pH}$-sensitive liposomes, may present a promising delivery system for cisplatin-based cancer treatment. This liposome system proved to be able to circumvent the cisplatin resistance, whereas it was not observed when using non-long-circulating liposomes composed of phosphatidylcholine, phosphatidylserine, and cholesterol.
Key words - Cisplatin

- Liposomes

- Encapsulation

- Cytotoxicity 


\section{Introduction}

cis-Diamminedichloroplatinum (II) (CDDP) or cisplatin is one of the most effective chemotherapeutic agents used for the treatment of ovary, lung, testicle, head, and neck carcinoma (1-5). However, its use presents some inconveniences, such as development of resistance in human ovarian cell line A2780, cervical cancer cell line ME180 and colon carcinoma cell line LoVo; side effects, principally nephrotoxicity, and chemical incompatibility with other drugs used simultaneously in polychemotherapy, such as etoposide and thiotepa $(6,7)$. The appearance of resistance during therapy is an important limitation to the use of CDDP, leading to treatment failure (8-11). The use of higher doses of CDDP is not desirable due to the toxicity of the drug to multiple organs, such as damage to the kidneys and bone marrow, intractable vomiting, peripheral neuropathy, deafness, seizures, and blindness (12-14). The reasons for resistance to cisplatin have been reported to be multifactorial. Four main events accompany it in most cases: i) decreased accumulation of drug concentration (to below that necessary for cytotoxic activity), ii) increased levels of sulfur-containing molecules such as glutathione or metallothionein (which could play a role in metal detoxification), iii) enhanced repair of DNA damage caused by CDDPDNA adducts by nucleotide excision repair proteins such as ERCC1, XPA, and XPB which can remove DNA adducts produced by CDDP, and iv) increased tolerance to CDDP-DNA adducts as a consequence of deficiencies in the mismatch repair system and enhanced replication bypass (15-18). Among the various resistance mechanisms involved, decreased cellular accumulation of CDDP has been demonstrated in most cases (19-24). Reduced intracellular CDDP concentration results in decreased DNA platination, which leads to CDDP resistance. The mechanism by which CDDP enters cells is not known. It has been postulated that cellular uptake of CDDP occurs by passive diffusion; however, some reports support a protein-mediated transport $(21,24-26)$.

Thus, the employment of new delivery systems of CDDP such as stealth $\mathrm{pH}$-sensitive liposomes can be a strategy to overcome these limitations. The encapsulation of CDDP into $\mathrm{pH}$-sensitive liposomes can improve its entry into cells, can lead to an another pharmacokinetics profile, reducing or eliminating the side effects, and can allow the association with other drugs without the appearance of degradation products. These liposomes are generally taken up by the cells through an endocytosis process. The release of CDDP into the cytoplasm results from the ability of these liposomes to cross the endosomal membrane. Inside endosomes, the stealth $\mathrm{pH}$-sensitive liposomes are exposed to an acidic medium, pH 5.5-6.5, which provokes their fusion with and the destabilization of the endosome membrane. Then, the encapsulated content is delivered into the cytoplasm $(27,28)$. Therefore, in the present study, we investigated the encapsulation of CDDP into stealth $\mathrm{pH}$-sensitive liposomes, the cytotoxic activity of the preparation, and its ability to circumvent CDDP resistance using A549, A431, BHK-21, and GLC4, GLC4/CDDP cell lines, respectively.

\section{Material and Methods}

\section{Material}

Cisplatin was supplied by Quiral Química do Brasil S.A. (Juiz de Fora, MG, Brazil). Distearoylphosphatidylethanolamine-polyethyleneglycol (DSPE-PEG) and dioleoylphosphatidylethanolamine (DOPE) were supplied by Lipoid GmBh (Ludwigshafen, Germany). Cholesteryl hemisuccinate (CHEMS) was purchased from Sigma (St. Louis, MO, USA), and sodium chloride was purchased from Merck (Rio de Janeiro, RJ, Brazil). 


\section{Preparation of liposomes}

Initially, DOPE, CHEMS, and DSPE$\mathrm{PEG}_{2000}$ were dissolved in chloroform (lipid concentration 20,30 , and $40 \mathrm{mM}$; molar ratio 5.7:3.8:0.5) and were transferred to a round bottom flask and submitted to evaporation. The lipid film obtained was dissolved in ethyl ether and then added to the $2 \mathrm{mg} / \mathrm{mL}$ CDDP solution prepared in $0.9 \% \mathrm{NaCl}$. The ratio of the aqueous to ether phase was 1:3. The resulting mixture was submitted to fast vortex agitation to produce a type of water/ oil emulsion. Next, ethyl ether was evaporated, with the resulting formation of liposomes. These liposomes were submitted or not to filtration through $0.4-\mu \mathrm{m}$ and $0.2-\mu \mathrm{m}$ polycarbonate membranes (5 cycles each) and the unencapsulated CDDP was eliminated by ultracentrifugation with a Sorvall Ultra 80 ultracentrifuge (Albertville, MN, USA) at $150,000 \mathrm{~g}$ at $10^{\circ} \mathrm{C}$ for $60 \mathrm{~min}$.

\section{Characterization of liposomes}

The liposomes were characterized on the basis of their encapsulation percentage, size and zeta potential. The encapsulation percentage of CDDP into liposomes was determined by high-performance liquid chromatography. The chromatographic apparatus consisted of a Model 515 pump (Waters Instruments, Milford, MA, USA), a Model 717 Plus auto-injector (Waters Instruments) and a Model 2487 variable wavelength UV detector (Waters Instruments) connected to the Millennium software. Separations were done using Lichrospher ${ }^{\circledR} 100 \mathrm{NH} 2$ guard column, 4 x 4 mm, 5 нm (Merck, Darmstadt, Germany) connected to a $25 \mathrm{~cm} \mathrm{x} 4 \mathrm{~mm}$ Lichrospher ${ }^{\circledR} 100$ NH2 column, 10- $\mu$ m particles (Merck). The eluent system was composed of methanol/ethyl acetate/N,N-dimethylformamide/water, $4: 4: 1: 1$, and the flow rate was $1.0 \mathrm{~mL} / \mathrm{min}$. Samples $(20 \mu \mathrm{L})$ were injected and the eluate absorbance was monitored at $310 \mathrm{~nm}$. The amount of CDDP was determined in the stock solution employed for the preparation of liposomes and in the supernatant. The encapsulation percentage (EP) was calculated as:

$$
\begin{array}{r}
\mathrm{EP}=[\mathrm{CDDP}]_{\text {liposomes before ultracentrifugation }} \text { minus } \\
{[\mathrm{CDDP}]_{\text {supernatant }} \times 100} \\
{[\mathrm{CDDP}]_{\text {liposomes before ultracentrifugation }}}
\end{array}
$$

The loading capacity was assessed by measuring inorganic phosphorus (29). The mean diameter of the liposomes-containing CDDP was determined by the quasi-elastic light scattering, at $25^{\circ} \mathrm{C}$ and at an angle of $90^{\circ}$. The zeta potential was evaluated by the determination of electrophoretic mobility at the $90^{\circ}$ angle. The measurements were performed in triplicate using the 3000 HS Zetasizer equipment (Malvern Instruments, Worcestershire, England). The samples were diluted with a $0.9 \% \mathrm{NaCl}$.

\section{Liposome stability}

Stealth $\mathrm{pH}$-sensitive liposomes containing CDDP were diluted 10-fold in $0.9 \%$ $\mathrm{NaCl}, \mathrm{pH} 6.5$, or mouse plasma, $\mathrm{pH} 7.4$, and incubated at $37^{\circ} \mathrm{C}$ for $30 \mathrm{~min}$. The platinum released from liposomes containing CDDP was separated and determined by ultracentrifugation at $150,000 \mathrm{~g}, 10^{\circ} \mathrm{C}$, for $60 \mathrm{~min}$ followed by graphite furnace atomic absorption spectrometry (Springvale, Victoria, Australia).

\section{Cytotoxicity assay}

The human lung cancer cell line A549 and human cervix squamous carcinoma cell line A431 were cultured in modified DEMEN medium supplemented with $10 \%$ fetal bovine serum. The Baby Hamster Kidney cell line (BHK-21) was grown in RPMI 1640 medium supplemented with $10 \%$ fetal bovine serum. All cell lines were maintained at $36.5^{\circ} \mathrm{C}$ in a humidified $2.5 \% \mathrm{CO}_{2}$ atmosphere. An aliquot containing $4 \times 10^{3} \mathrm{BHK}$ 
cells, 5 x 103 A549 or A431 cells was distributed in 96-well plates. After $24 \mathrm{~h}$ of growth, the cells were submitted to treatment with free CDDP, stealth $\mathrm{pH}$-sensitive liposomes containing CDDP and empty stealth $\mathrm{pH}-$ sensitive liposomes. The CDDP concentration employed was $79.4 \mathrm{nM}, 3.7$ and 0.46 $\mu \mathrm{M}$ for the A431, A549 and BHK cells, respectively. These concentrations correspond to the $\mathrm{IC}_{50}$ of CDDP for each cell line. The treatment was performed on three consecutive days, with a change of the culture medium for each new treatment. Seventytwo hours after the initial treatment, cell viability was assessed by 3-[4,5-dimethylthiazol-2yl]-diphenyltetrazolium bromide (MTT) reduction. First, $10 \mu \mathrm{L}$ of a $5-\mathrm{mg} / \mathrm{mL}$ tetrazolium salt solution was added to each well of the plate. After $4 \mathrm{~h}$, MTT crystals were solubilized in $150 \mu \mathrm{L}$ dimethylsulfoxide. Absorbance readings were performed at 600 nm using a Stat Fax 2100 spectrophotometer (Awareness Technology, Inc., Palm City, FL, USA). Data were analyzed by twoway ANOVA and the means were compared by applying the Bonferroni test $(\mathrm{P} \leq 0.05)$ using the GraphPad Prism, version 4.0, software.

\section{Evaluation of resistance of cisplatin}

The GLC4 cell line was derived from the pleural effusion of a patient with small cell lung carcinoma in the laboratories of Prof. E.G.E. de Vries (Department of Internal Medicine, University Hospital, Groningen, The Netherlands). The GLC4/CDDP subline was obtained by continuous exposure to CDDP. The cell lines were cultured in RPMI 1640 medium supplemented with $10 \%$ fetal calf serum at $37^{\circ} \mathrm{C}$ in a humidified $5 \% \mathrm{CO}_{2}$ atmosphere. Cultures were initiated at $10^{5}$ cells $/ \mathrm{mL}$ and grew exponentially to about $10^{6}$ cells $/ \mathrm{mL}$ within three days. Cell viability was checked by Trypan blue exclusion. The number of cells was determined by Coulter counter analysis. For the long-term growth inhibition $1 \times 10^{5}$ cells $/ \mathrm{mL}$ were cultured for $72 \mathrm{~h}$ in the presence and absence of different concentrations of CDDP encapsulated or not into stealth $\mathrm{pH}$-sensitive liposomes. The sensitivity to the drug was evaluated by the $\mathrm{IC}_{50}$, i.e., the drug concentration needed to inhibit cell growth by $50 \%$. A resistance factor (RF) was obtained by dividing the $\mathrm{IC}_{50}$ of resistant cells by the $\mathrm{IC}_{50}$ of sensitive cells. $\mathrm{RF}$ is equal to 6.3 for CDDP and CDDP resistance is stable for at least 8 months (24).

\section{Determination of cellular platinum concentrations}

Cells were incubated with different concentrations of CDDP or CDDP containing stealth $\mathrm{pH}$-sensitive liposomes for 3 days. After incubation, an aliquot was taken and washed twice with ice-cold PBS and the pellet was resuspended in $65 \% \mathrm{HNO}_{3}$. Platinum concentration was determined by atomic absorption spectroscopy using a Varian model Zeeman 220 spectrophotometer (Mulgrave, Victoria, Australia) equipped with a graphite tube atomizer and an autosampler.

\section{Results and Discussion}

\section{Preparation of stealth $\mathrm{pH}$-sensitive liposomes containing CDDP}

Formulation studies showed that the encapsulation of CDDP was significantly improved by increasing the amount of lipids used. Percent CDDP entrapment ranged from 6.6 to $18.6 \%$ depending on the lipid concentration (Table 1). The loading capacity of liposomes also increased when the lipid concentration varied only from 30 to $40 \mathrm{mM}$ (Table 1). However, these liposomes showed a heterogeneous size distribution $(444.5 \mathrm{~nm}$, polydispersity index equal to 0.6 ) that could induce the destabilization of the vesicles, provoking the release of CDDP. Thus, these liposomes were submitted to extrusion 
against 0.4 and $0.2 \mu \mathrm{m}$ polycarbonate membranes before purification by ultracentrifugation. However, the size reduction did not alter the entrapment percentage $(20.0 \%)$, but produced a vesicle suspension of homogeneous diameter (174 nm, polydispersity index equal to 0.03 ) and a zeta potential equal to $1.6 \mathrm{mV}$. The liposomes containing the largest amount of CDDP were chosen for the evaluation of cytotoxicity and resistance.

\section{Liposome stability}

Stealth $\mathrm{pH}$-sensitive liposomes containing CDDP showed good stability in proteinrich medium such as mouse plasma. Approximately $70 \%$ CDDP remained inside the liposomes after their incubation in this medium. The leakage of CDDP from the liposomes exposed to $0.9 \% \mathrm{NaCl}$ was similar, with no significant difference $(\mathrm{P}<0.05)$. Probably, the release of CDDP from liposomes was due to heating $\left(37^{\circ} \mathrm{C}\right)$ and not to the destabilization provoked by interactions with plasma proteins.

\section{Cytotoxicity}

Figure 1 illustrates the cytotoxic effects of CDDP encapsulated or not into stealth $\mathrm{pH}$-sensitive liposomes on normal and tumor cell lines. The cytotoxic activity of stealth $\mathrm{pH}$-sensitive liposomes containing CDDP was higher than that of free CDDP against the A549 cell line $(\mathrm{P}<0.05)$. However, these liposomes did not prove to be more effective against the A431 cell line. Cell growth inhibition was lower with the encapsulation of CDDP into stealth $\mathrm{pH}$-sensitive liposomes. The same effect was observed for the GLC4 cell line (Table 2). The cellular sensitivity to CDDP encapsulated into stealth $\mathrm{pH}$-sensitive liposomes was lower than for free CDDP, as revealed by the determination of the $\mathrm{IC}_{50}$. These findings suggest that the cytotoxic activity of these liposomes containing CDDP is dependent on the cell line type. Statistical analysis indicated the influence of cell type on the response to treatment with free CDDP or with stealth $\mathrm{pH}$-sensitive liposomes containing CDDP. The A549 cells showed higher sensitivity to treatment with stealth $\mathrm{pH}$-sensitive liposomes containing CDDP than A431 cells $(\mathrm{P}=0.0006)$. Perhaps, the cell lineassociated differences in the efficacy of stealth $\mathrm{pH}$-sensitive liposomes containing CDDP are related to the uptake mechanisms

Table 1. Effect of lipid concentration on the encapsulation of CDDP into stealth $\mathrm{pH}$ sensitive liposomes.

\begin{tabular}{lrc}
\hline $\begin{array}{l}\text { Lipid concentration during } \\
\text { preparation of liposomes }\end{array}$ & Entrapment (\%) & $\begin{array}{c}\text { Loading capacity } \\
\text { (mg CDDP/nmol lipid) }\end{array}$ \\
\hline $20 \mathrm{mM}$ & $6.95 \pm 0.32$ & $10.96 \pm 0.35$ \\
$30 \mathrm{mM}$ & $8.80 \pm 0.29$ & $10.20 \pm 0.92$ \\
$40 \mathrm{mM}$ & $18.60 \pm 1.26$ & $14.32 \pm 0.81$ \\
\hline
\end{tabular}

Data are reported as means \pm SD for three determinations. CDDP $=$ cis-diamminedichloroplatinum (II) (cisplatin).

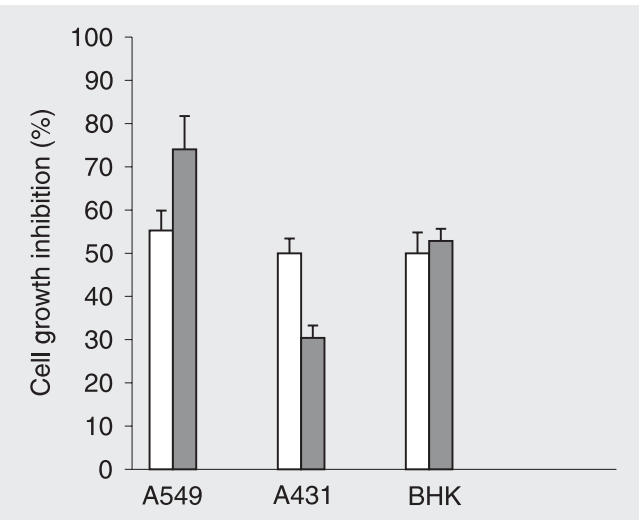

Figure 1. Cytotoxic activity of free CDDP (open bars) and of stealth $\mathrm{pH}$-sensitive liposomes containing CDDP (filled bars). Data are reported as means \pm $\mathrm{SD}$ and were obtained from six experiments. $\mathrm{CDDP}=$ cis-diamminedichloroplatinum (II) (cisplatin); A549 = human lung cancer cell line; A431 = human cervix squamous carcinoma cell line; BHK-21 = Baby Hamster Kidney cell line.

Table 2. $I_{50}$, resistance factor $(\mathrm{RF})$ and intracellular platinum concentrations after 3 days of incubation with CDDP or liposomal CDDP.

\begin{tabular}{lcccc}
\hline Compound & Cell line & $\mathrm{IC}_{50}(\mu \mathrm{M})$ & $\mathrm{RF}$ & {$[\mathrm{Pt}]_{\mathrm{i}} \times 10^{17}(\mathrm{~mol} / \mathrm{cell})$} \\
\hline CDDP & GLC4 & $0.40 \pm 0.05$ & & 9.8 \\
CDDP & GLC4/CDDP & $2.50 \pm 0.20$ & 6.3 & 10.7 \\
Liposomal CDDP & GLC4 & $1.32 \pm 0.10$ & & 4.0 \\
Liposomal CDDP & GLC4/CDDP & $1.45 \pm 0.15$ & 1.1 & 4.0
\end{tabular}

$I_{50}$ is the CDDP concentration required to inhibit cell growth by $50 \%$. The resistance factor (RF) is the $\mathrm{IC}_{50}$ of the resistant cells divided by the $\mathrm{IC}_{50}$ of the sensitive cells. $[P t]_{i}$ is the intracellular platinum concentration. Data are reported as the mean $\pm \mathrm{SD}$ of triplicate determinations. CDDP = cis-diamminedichloroplatinum (II) (cisplatin). 
involved in each cell line. Lim et al. (30) demonstrated different levels of liposomal mitoxantrone accumulation in LS180 human colon carcinoma tumors compared to

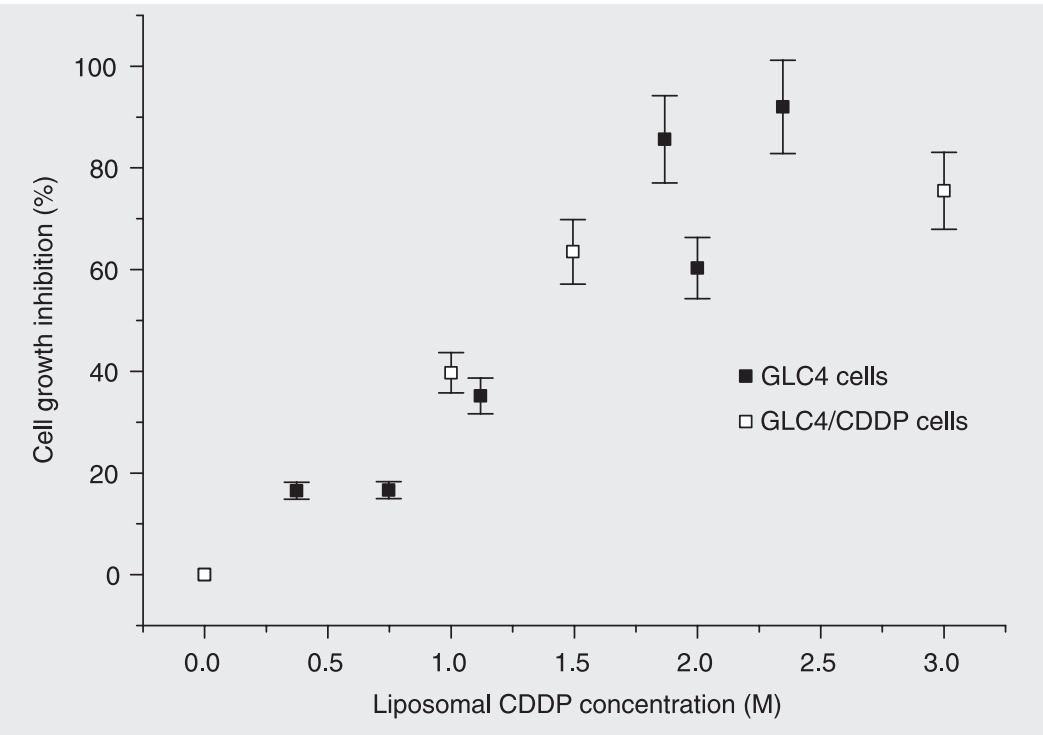

Figure 2. Dose-response curves of GLC4 and GLC4/CDDP cells for stealth pH-sensitive liposomes of CDDP obtained after 3 days of incubation. Data are reported as means \pm SD for three experiments. GLC4 = human small-cell lung carcinoma cell line; CDDP = cisdiamminedichloroplatinum (II) (cisplatin).

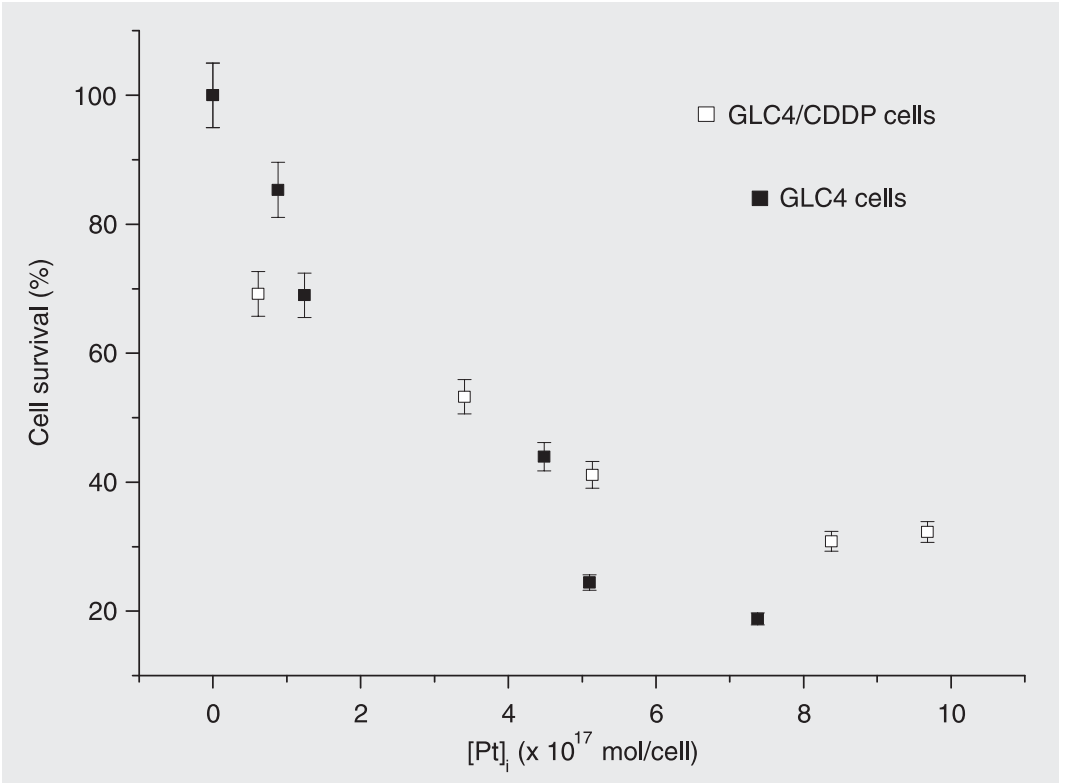

Figure 3. Cell survival as a function of intracellular platinum concentration after equitoxic drug exposure for 3 days. Data are reported as means \pm SD for three independent experiments. GLC4 = human small-cell lung carcinoma cell line; CDDP $=$ cis-diamminedichloroplatinum (II) (cisplatin).
A431 tumors. This finding has been attributed to the more rapid liposome uptake in the LS180 cell line. The cytotoxicity of free or liposome-encapsulated CDDP on the BHK cell line was identical. This cell line was chosen for the assay due to the renal toxicity induced by the use of CDDP. In spite of this finding, it should be pointed out that the biodistribution behavior of the free drug and of the drug encapsulated into nanostructured systems is not the same. Júnior et al. (31) and Newman et al. (32) obtained different pharmacokinetics profiles from administration of liposomal formulations containing CDDP in comparison with free CDDP. In both studies, a lower renal accumulation of CDDP from liposomal CDDP treatment was observed than that from free CDDP. Thus, the in vivo toxicologic response to stealth $\mathrm{pH}$ sensitive liposomes containing CDDP can be modified, avoiding the occurrence of kidney failure. No cell growth inhibition was observed with empty stealth $\mathrm{pH}$-sensitive liposomes.

\section{Drug sensitivity}

The effect of stealth $\mathrm{pH}$-sensitive liposomes containing CDDP on the growth of the GLC4 and GLC4/CDDP cell lines is shown in Figure 2. One can observe that the response of both cell lines to a given dose of this new cisplatin formulation was comparable. Table 2 shows the drug concentration that inhibits cell growth by $50 \%$ and the RF obtained. For the sake of comparison, CDDP data are also shown. Intriguingly, the cytotoxic activity of stealth $\mathrm{pH}$-sensitive liposomes containing CDDP on the sensitive cell line was inferior to that of free CDDP. This fact is probably related to different uptake mechanisms of the free and the encapsulated CDDP.

\section{Drug accumulation after equitoxic exposure}

The percentage of growth inhibition ver- 
sus the content of platinum within the cell determined in GLC4 and in GLC4/CDDP is plotted in Figure 3. Comparing platinum accumulation in the two cell lines, one notices that almost the same levels of platinum are necessary to produce a certain cytotoxic effect. For example, incubation of CDDP with stealth $\mathrm{pH}$-sensitive liposomes at $\mathrm{IC}_{50}$ doses yielded a comparable $[\mathrm{Pt}]_{\mathrm{i}}$ for both sensitive and resistant cells of about $4 \mathrm{x}$ $10^{-17} \mathrm{~mol} / \mathrm{cell}$. We have previously shown that the accumulation of CDDP in both GLC4 and GLC4/CDDP cell lines follows the same pattern, i.e., incubation with equitoxic doses yields practically the same intracellular platinum levels. For example, incubation with $\mathrm{CDDP}_{\text {at }} \mathrm{IC}_{50}$ doses $(\mathrm{glc} 4=0.4 \mu \mathrm{mol} / \mathrm{L}$ and GLC4/CDDP $=2.5 \mu \mathrm{mol} / \mathrm{L}$ ) yielded comparable $[\mathrm{Pt}]_{\mathrm{i}}$ of $10 \times 10^{-17} \mathrm{~mol} / \mathrm{cell}$ for both sensitive and resistant cells. These results show the importance of transport as a mechanism of resistance to CDDP exhibited by GLC4/CDDP cells. In the case of free CDDP, it was necessary to use a higher dose to force its uptake by GLC4/CDDP cells, a fact that was not observed with the use of stealth $\mathrm{pH}$ sensitive liposomes containing CDDP. CDDP encapsulated into stealth $\mathrm{pH}$-sensitive liposomes enters sensitive cells as easily as resistant cells. The liposomal formulation exhibited the same efficacy against CDDPsensitive and CDDP-resistant cells, with an RF equal to 1.1 (Table 2). This factor is much lower than that for non-encapsulated CDDP, which is equal to 6.3 (24). Thus, these liposomes were able to overcome the resistance mechanisms. In addition, the lower intracellular platinum concentration detected when the cells were incubated with an equitoxic CDDP concentration $\left(\mathrm{IC}_{50}\right)$ suggests the occurrence of a different transport mechanism for stealth $\mathrm{pH}$-sensitive liposomes. Aqueous formulations of CDDP are solutions of the native and hydrated forms of the drug in equilibrium, which is dependent on the $\mathrm{pH}$ and $\mathrm{Cl}^{-}$concentrations. Chloride ions can be replaced with water molecules, which in turn can be hydrolyzed, yielding hydroxy species. The most important product, the monohydrated species, $\left[\mathrm{Pt}\left(\mathrm{NH}_{3}\right)_{2}\right.$ $\left.\left(\mathrm{OH}_{2}\right) \mathrm{Cl}\right]^{+}$, is formed by the following reaction:

cis- $\left[\mathrm{Pt}\left(\mathrm{NH}_{3}\right)_{2} \mathrm{Cl}_{2}\right]+\mathrm{H}_{2} \mathrm{O} \leftrightarrows$ cis- $\left[\mathrm{Pt}\left(\mathrm{NH}_{3}\right)_{2}\left(\mathrm{OH}_{2}\right) \mathrm{Cl}\right]^{+}+\mathrm{Cl}^{-}$

We have previously proposed that CDDP uptake by sensitive GLC4 cells is the sum of two components: an energy-dependent pathway and passive diffusion. The active component is deficient in the GLC4/CDDP subline. The actively transported species is hydro-derivative, probably $\left[\mathrm{Pt}\left(\mathrm{NH}_{3}\right)_{2}\left(\mathrm{H}_{2} \mathrm{O}\right)\right.$ $\mathrm{OH}]^{+}$or $\left[\mathrm{Pt}\left(\mathrm{NH}_{3}\right)_{2}\left(\mathrm{H}_{2} \mathrm{O}\right) \mathrm{Cl}\right]^{+}(24)$. Cationic aquated species are more reactive with DNA, producing intra- and inter-strand adducts and, consequently, the cytotoxic effects. Therefore, one can speculate that the CDDP delivery by stealth $\mathrm{pH}$-sensitive liposomes favors the formation of hydrated species. It is known that CDDP is almost completely converted to the monohydro species at $\mathrm{pH} 6.0$ (80\%) (33). As the stealth $\mathrm{pH}$-sensitive liposomes enter the cells by endocytosis, the release of CDDP might occur as a consequence of the acidification process inside the endosomes, as explained above. Inside late endosomes the $\mathrm{pH}$ ranges from 5.5 to 6.0 , and consequently, the main species present is the aquohydroxy-derivative. This could explain the achievement of a similar cytotoxicity level with the presence of a lower intracellular platinum concentration.

Finally, it is noteworthy that the stealth pH-sensitive liposomes might offer advantages over conventional liposomes due to their ability to deliver their contents into the cytoplasm. These liposomes can be an alternative to solve the clinical failure observed with the use of stealth liposomes in the treatment of neck and head carcinoma (34). The authors believe that the clinical inefficacy results from the low release of CDDP. To solve this problem would be appropriate to improve liposome composition. Thus, the 
present study allowed us to determine more adequate conditions for the encapsulation of CDDP into stealth $\mathrm{pH}$-sensitive liposomes. These stealth $\mathrm{pH}$-sensitive liposomes are stable in plasma and this finding is important to the in vivo evaluation of their antitumoral efficacy and pharmacokinetics. Moreover, these liposomes proved to be active against a type of lung tumor cell line (A549) and to provide an excellent strategy to circumvent the pre-clinical resistance to treatment with CDDP. These carriers were able to introduce the same level of CDDP into resistant and sensitive cells after incubation with equal CDDP concentrations.

\section{Acknowledgments}

The authors gratefully acknowledge Lipoid $\mathrm{GmBh}$ and Quiral Química do Brasil S.A. for providing materials. We are also grateful to Prof. Elzíria Aguiar Nunan for help with the statistical analysis.

\section{References}

1. Kondagunta GV, Bacik J, Donadio A, Bajorin D, Marion S, Sheinfeld $\mathrm{J}$, et al. Combination of paclitaxel, ifosfamide, and cisplatin is an effective second-line therapy for patients with relapsed testicular germ cell tumors. J Clin Oncol 2005; 23: 6549-6555.

2. Guillot T, Spielmann M, Kac J, Luboinski B, Tellez-Bernal E, Munck $\mathrm{JN}$, et al. Neoadjuvant chemotherapy in multiple synchronous head and neck and esophagus squamous cell carcinomas. Laryngoscope 1992; 102: 311-319.

3. Le Chevalier T, Brisgand D, Douillard JY, Pujol JL, Alberola V, Monnier A, et al. Randomized study of vinorelbine and cisplatin versus vindesine and cisplatin versus vinorelbine alone in advanced non-small-cell lung cancer: results of a European multicenter trial including 612 patients. J Clin Oncol 1994; 12: 360-367.

4. Shirazi FH, Molepo JM, Stewart DJ, Ng CE, Raaphorst GP, Goel R. Cytotoxicity, accumulation, and efflux of cisplatin and its metabolites in human ovarian carcinoma cells. Toxicol Appl Pharmacol 1996; 140: 211-218.

5. Muggia FM, Fojo T. Platinums: extending their therapeutic spectrum. J Chemother 2004; 16 (Suppl 4): 77-82.

6. Stewart CF, Hampton EM. Stability of cisplatin and etoposide in intravenous admixtures. Am J Hosp Pharm 1989; 46: 1400-1404.

7. Trissel LA, Martinez JF. Compatibility of thiotepa (lyophilized) with selected drugs during simulated Y-site administration. Am J Health Syst Pharm 1996; 53: 1041-1045.

8. Hospers GA, Mulder NH, de Jong B, de Ley L, Uges DR, FichtingerSchepman AM, et al. Characterization of a human small cell lung carcinoma cell line with acquired resistance to cis-diamminedichloroplatinum (II) in vitro. Cancer Res 1988; 48: 6803-6807.

9. Muggia FM, Los G. Platinum resistance: laboratory findings and clinical implications. Stem Cells 1993; 11: 182-193.

10. Siddik $\mathrm{ZH}$. Cisplatin: mode of cytotoxic action and molecular basis of resistance. Oncogene 2003; 22: 7265-7279.

11. Wernyj RP, Morin PJ. Molecular mechanisms of platinum resistance: still searching for the Achilles' heel. Drug Resist Updat 2004; 7: 227-232.

12. Chu G. Cellular responses to cisplatin. The roles of DNA-binding proteins and DNA repair. J Biol Chem 1994; 269: 787-790.

13. Conti M, De Giorgi U, Tazzari V, Bezzi F, Baccini C. Clinical pharmacology of intraperitoneal cisplatin-based chemotherapy. J Chemother 2004; 16 (Suppl 5): 23-25.
14. Ekborn A, Hansson J, Ehrsson H, Eksborg S, Wallin I, Wagenius G, et al. High-dose cisplatin with amifostine: ototoxicity and pharmacokinetics. Laryngoscope 2004; 114: 1660-1667.

15. Kelland LR. Preclinical perspectives on platinum resistance. Drugs 2000; 59 (Suppl 4): 1-8.

16. Oldenburg J, Begg AC, van Vugt MJ, Ruevekamp M, Schornagel $\mathrm{JH}$, Pinedo HM, et al. Characterization of resistance mechanisms to cis-diamminedichloroplatinum (II) in three sublines of the CC531 colon adenocarcinoma cell line in vitro. Cancer Res 1994; 54: 487493.

17. Santarpia M, Altavilla G, Salazar F, Taron M, Rosell R. From the bench to the bed: individualizing treatment in non-small-cell lung cancer. Clin Transl Oncol 2006; 8: 71-76.

18. Jakupec MA, Galanski M, Keppler BK. Tumour-inhibiting platinum complexes - state of the art and future perspectives. Rev Physiol Biochem Pharmacol 2003; 146: 1-54.

19. Dzamitika S, Salerno M, Pereira-Maia E, Le Moyec L, GarnierSuillerot A. Preferential energy- and potential-dependent accumulation of cisplatin-glutathione complexes in human cancer cell lines (GLC4 and K562): A likely role of mitochondria. J Bioenerg Biomembr 2006; 38: 11-21.

20. Schmidt W, Chaney SG. Role of carrier ligand in platinum resistance of human carcinoma cell lines. Cancer Res 1993; 53: 799-805.

21. Gately DP, Howell SB. Cellular accumulation of the anticancer agent cisplatin: a review. Br J Cancer 1993; 67: 1171-1176.

22. Lanzi C, Perego P, Supino R, Romanelli S, Pensa T, Carenini N, et al. Decreased drug accumulation and increased tolerance to DNA damage in tumor cells with a low level of cisplatin resistance. Biochem Pharmacol 1998; 55: 1247-1254.

23. Cesar ET, de Almeida MV, Fontes AP, Pereira Maia EC, GarnierSuillerot A, Rubia Costa CM, et al. Synthesis, characterization, cytotoxic activity, and cellular accumulation of dinuclear platinum complexes derived from N,N'-di-(2-aminoethyl)-1,3-diamino-2-propanol, aryl substituted N-benzyl-1,4-butanediamines, and N-benzyl1,6-hexanediamines. J Inorg Biochem 2003; 95: 297-305.

24. Pereira-Maia E, Garnier-Suillerot A. Impaired hydrolysis of cisplatin derivatives to aquated species prevents energy-dependent uptake in GLC4 cells resistant to cisplatin. J Biol Inorg Chem 2003; 8: 626634.

25. Andrews PA, Mann SC, Huynh $\mathrm{HH}$, Albright KD. Role of the $\mathrm{Na}$, 
$\mathrm{K}(+)$-adenosine triphosphatase in the accumulation of cis-diamminedichloroplatinum (II) in human ovarian carcinoma cells. Cancer Res 1991; 51: 3677-3681.

26. Beretta GL, Gatti L, Tinelli S, Corna E, Colangelo D, Zunino F, et al. Cellular pharmacology of cisplatin in relation to the expression of human copper transporter CTR1 in different pairs of cisplatin-sensitive and -resistant cells. Biochem Pharmacol 2004; 68: 283-291.

27. Collins D. pH-sensitive liposomes as tools for cytoplasmic delivery. In: Philippot R, Schuber F (Editors), Liposomes as tools in basic research and industry. Boca Raton: CRC Press; 1995. p 201-214.

28. De Oliveira MC, Boutet V, Fattal E, Boquet D, Grognet JM, Couvreur $\mathrm{P}$, et al. Improvement of in vivo stability of phosphodiester oligonucleotide using anionic liposomes in mice. Life Sci 2000; 67: 16251637.

29. New RRC. Characterization of liposomes. In: New RRC (Editor), Liposomes a pratical approach. New York: Oxford University Press; 2000. p 105-161.

30. Lim HJ, Masin D, Mclntosh NL, Madden TD, Bally MB. Role of drug release and liposome-mediated drug delivery in governing the thera- peutic activity of liposomal mitoxantrone used to treat human A431 and LS180 solid tumors. J Pharmacol Exp Ther 2000; 292: 337-345.

31. Júnior AD, Mota LG, Nunan EA, Wainstein AJ, Wainstein AP, Leal $\mathrm{AS}$, et al. Tissue distribution evaluation of stealth $\mathrm{pH}$-sensitive liposomal cisplatin versus free cisplatin in Ehrlich tumor-bearing mice. Life Sci 2007; 80: 659-664.

32. Newman MS, Colbern GT, Working PK, Engbers C, Amantea MA. Comparative pharmacokinetics, tissue distribution, and therapeutic effectiveness of cisplatin encapsulated in long-circulating, pegylated liposomes (SPI-077) in tumor-bearing mice. Cancer Chemother Pharmacol 1999; 43: 1-7.

33. Yachnin JR, Wallin I, Lewensohn R, Sirzen F, Ehrsson H. The kinetics and cytotoxicity of cisplatin and its monohydrated complex. Cancer Lett 1998; 132: 175-180.

34. Harrington KJ, Lewanski CR, Northcote AD, Whittaker J, Wellbank $\mathrm{H}$, Vile RG, et al. Phase I-II study of pegylated liposomal cisplatin (SPI-077) in patients with inoperable head and neck cancer. Ann Oncol 2001; 12: 493-496. 